\title{
Influence of Principals role in setting direction on academic performance: Perceptions in Public Secondary Schools in Kisumu County, Kenya.
}

\author{
Elizabeth Akinyi Okoth ${ }^{1}$ Kennedy Nyambeche Getange ${ }^{2}$ \\ Faculty of Education, Kisii University, P.O.Box 408-40200, Kisii, Kenya
}

\begin{abstract}
Principals play a vital role in providing leadership for delivery of quality education in schools, they are continually held accountable for their schools' performance in national examinations. Some schools have experienced conflicts between stakeholders and principals over the same. Due to this 5\% (10 out of 204) principals in Kisumu County have been deployed as classroom teachers while $24.5 \%$ have been transferred. This study established the influence of setting direction as an aspect of transformational leadership practices by principals on students' academic performance in public secondary schools in Kisumu County.. The objective of the study was: to determine perceptions of teachers and students on the influence of principals'role in setting directions on academic performance in public secondary schools in Kisumu County. The study used a descriptive survey research design. The target population was 204 public secondary schools, 204 principals, 2196 teachers' and 13,213 form 3 students. The sample comprised 152 schools selected through stratified sampling, purposive sampling was used to select 152 principals and form 3 classes. Simple random was used to select 333 teachers and 378 students. Data was collected using questionnaires, interviews, direct observation and document analysis. Validity of the instruments was done by expert opinion, a test retest was done to determine the reliability of the instruments and a reliability index of 0.833 was reported. Qualitative data was analyzed thematically, while quantitative data analyzed descriptively using percentages, frequencies, mean and standard deviation. Hypothesis was tested at $\alpha=.05$ level of significance, The level of significance used was $95 \%(\alpha=$ $0.05)$ and where $\mathrm{p}<0.05$, one hypothesis was formulated; $\mathrm{H}_{01}$ : There is no significant influence on principals setting directions on students' academic performance, it was concluded that setting directions by the principals had a significant influence on the academic performance $p=.002, p<=0.05$ ), The study concluded that principal role in setting direction has a significant influence on academic performance of students.
\end{abstract}

Key words; Setting direction, Academic performance

DOI: $10.7176 / \mathrm{JEP} / 10-2-14$

\section{Research Objective}

The objective of this study was to establish the perceptions of students on the influence of principals' in setting directions on students' academic performance in secondary schools in Kisumu County.

\section{Research Question \\ This study was guided by the research question:}

What are the perceptions of students on the influence of principals in setting directions on students' academic performance in secondary schools in Kisumu County?

\section{Research Hypothesis}

The question above was further analyzed by the following null hypotheses: $\mathbb{I}_{01}$ : There is no significant influence on principals setting directions on students' academic performance in secondary schools in Kisumu County.

\subsection{Introduction}

School leaders are the players in charge of translating educational goals of a country into practice. The quality of leadership they provide is one of the chief factors in the achievement of high quality academic performance of 
students. According to the United States of America's (USA) Every Students Succeeds Act 2015, a school principal is very essential to school improvement and instructions. This Act recognizes that school leaders are powerful drivers of students' outcome and as such the Act invests in principals as part of schools' improvements in the USA (Herman, Gates, Chavez-Herrerias \& Harris 2016). Several researches have recognized that a school principal matter in issues affecting high school students outcome, Coelli and Green 2012; Dhuey and Smith2014 and Loeb; and Kalogridges 2012). These studies have demonstrated that actually a school principals' is instrumental in students' academic achievement.

In a school structure, the principals are the leaders who provide fundamental insights into the daily school practices. The US Senate committee of 1972 report recognized the principal as the single most important and influential individual in the school. As Leithwood and Riehi (2003) noted that scratch the surface of an excellent school and you will find an excellent principal; peer into a falling school and you will find weak principal. Therefore a principal is the prime mover coordinating all the activities in the school. According to Limsila and Ogunlana (2008), in an educational organization, a principal is the manager of all educational activities; he/she makes available prospects for performance enhancement of teachers, and increased learning among students.

According to Castanheira and Costa (2011) transformational leaders have three basic functions: First, they sincerely serve the desires of others, empower them and stimulate them to attain great achievement. Secondly, they charismatically show the way, set a vision, inculcate trust, confidence and pride in working with them.

\subsection{Setting Directions and Academic Performance}

The first practice of transformational leadership as identified by Leithwood (2010) is setting direction. Setting direction means showing the way, it is being extremely clear regarding your intention. It includes activities like building a shared vision, fostering acceptance of group goals and high performance expectations. The school leader must know his vision, goals and objectives of the organization. Once a leader has a purpose for the journey, the followers would follow suit.

The Wallace foundation (2016) identified the components of setting direction as identifying and articulating the vision, fostering acceptance of group goals, creating high performance expectations, monitoring organizational performance and promoting effective communication throughout the organization. According to Leithwood et al., (2010), setting direction focuses on the activities of the leader that builds a clear vision, establish goals, and create high performance expectations. Setting directions also involves effective communication. These are the dimensions that a school leader should establish as a transformational leader. Mehdi (2013) points out that sharing a clear wide direction provides a sense of purpose and identity and gives the school a way to measure and monitor daily routines and to prioritize activities that directly contribute to furthering the schools direction, goals and vision. The vision is communicated not only through words, but also through actions taken.

According to Namango and Bichanga (2014) vision is an important element for accountability and autonomy, a principal must have a vision to lead a school towards academic success. They argued that if a school has a clear vision and strategic plan of reaching it, then the principal takes ownership of the school improvement.

A vision plays a critical role in the school set up; it is critical for academic performance because, the principal evaluates the current situation of the school, foresees the upcoming and work together with the institutions stakeholders to build up a vision that will yield an expected end. A vision inspires a school with a sense of direction. In setting direction the principal has a vision, where he envisions the school. Vision refers to an expansive image of the route in which one seeks move. According to Valentine and Prater (2011), one of the strongest correlates of student academic achievement is the ability to identify a vision for the school. Aydin (2012) found that the principals set high academic standards by visualizing success stories on the walls. A vision presents a sensible, credible, striking future for any school.

In setting direction the leader has a vision, where he envisions the organization. Vision refers to an expansive image of the route in which one seeks move. According to Limsila and Ogunlana, (2008) vision building is a deliberate process for creating a foundation built on an ambitious sense of purpose, which a school will strive to achieve over many years. Achieving the vision is accomplished by the establishment of school goals that are consistent with the curriculum. Effective leaders encourage others to envision where they want to be or where they want to go in the future (Starcher, 2006). Moreover, as Similarly Kouzes and Posner (2002) point out, best leadership experiences occur when leaders imagine an exciting, highly attractive future for their organizations. Transformational leaders are committed to working with their followers to develop and foster a shared vision among all stakeholders. 
In a study by Namango and Bichanga (2014) on the influence of strategic planning on academic performance in Kimilili - Bungoma County found that there is a positive and significant $(<0.05)$ between school vision and academic performance. The study population had principals, heads of departments and a district education officer only, however, in the current study students opinions about their principal were sought. The study had also principals and teachers.

A study by Grooms (2013) on articulated leadership practices of principals in relation to high performing schools, found that principals have an in direct effect on students achievement, the population of the study was limited to principals in urban districts, using a qualitative design, students performance was measured from national standardize exams and unlike the current study population was drawn from both urban and rural schools and performing and non performing schools. Grooms 2013, involved only principals the current study will incorporate both teachers and students, further more this study will use a mixed method of both qualitative and quantitative.

Another component of setting directions involves setting high performance expectations; according to Browning (2013) these are practices that display the leaders' expectations for excellence on the part of the follower. In order to perform well, teachers and students need to be reminded of what is expected of them. The principal communicates to teachers and students by describing the important functions and tasks expected of them in achieving the set objective of the school in line with the curriculum. The board of management and parents are not left out either. Principals setting performance expectations should aggressively work with the teachers in defining high academic expectations for their students. according to Murphy (2007) learning-focused principals translate the attitude of performance into school policies and practices that reflect and define positive expectations for students in the following ways: They lay more demands on teachers; they communicate their concern for the learners achievement; they establish clearly defined school wide academic standards; they develop standards that apply to all students; they hold more specific expectations; they create policies that encourage students to pursue more rigorous academic goals; they hold adults responsible for learning outcomes; they couple success with performance; and they require student mastery of grade level skills prior to entry in the following grade. (Murphy 2007)

On the effects of transformational leadership on academic optimism within 67 elementary schools in Northern Alabama Rutledge II (2010) did a study and established that setting direction was correlated to academic optimism. Rutledge II (2010) used Leithwood leadership instruments and school academic optimism survey. the current study also used Leithwood leadership instrument and KCSE mean score for a period of five years under study, it was also be carried out in Kenya, specifically in Kisumu County. The current study also incorporated 152 schools, principals, teachers and students. This was more than double the number of schools used by Rutledge (2010); he also left out views of students. The current study considered students views on how their principals set direction in the school.

In a study by Mgani (2013) using case study of three schools, on leadership style and school functioning in Kilosa district, Morogoro, Tanzania, established that out of the three schools only two schools had their principals setting and clarifying school goals, vision and mission to teachers and students while one school did not. Mgani collected data from teachers, students and principals through interviews, document analysis and observation. Though the current study also collected data from principals teachers and students it used both qualitative and quantitative analysis of data, it also used a descriptive survey.

A study by Valentine and Prater (2011) compared different forms of leadership exhibited by school principals and academic achievement of their students. They found that transformational leadership was strongly and positively related to academic performance. They concluded that three transformational leadership factors: (i) providing a model, (ii) identifying a vision and (iii) fostering group goals, mostly strongly explained students achievement scores in the study. According to Valentine and Prater (2011), one of the strongest correlates of student academic achievement was ability to identify a vision for the school. This finding emphasizes the importance of having a unified school goal or a vision. Valentine and Prater (2011) did not investigate setting directions, developing people, building collaborative structures and staffing the program. When a principal creates high expectations, the focus is on processes and outcomes. Transformational leaders encourage high performance expectations and utilize practices which demonstrate the leader's own expectations for excellence on the part of the followers.

Communication of expectations enhances teachers' perception of the gap between what the school is currently accomplishing and what it aspires to achieve (Limsila \& Ogunlana, 2008). In a school, there should be effective communication from the principal to teachers and students in order to achieve objectives of the school. Through 
this, the principal can encourage teachers and students into achieve the goals of the school and set the pace for the institution. According to Leithwood (2008), the performance of a school is dependent on focus and effectiveness of a school's leadership. While students reveal their ability to learn through achievement, attendance, and participation in school activities, the principals should set high academic standards and motivate both teachers and students towards achieving excellent academic results.

In a study by Ndinza (2015) on the influence of Head teachers Management practices on students' academic performance in Kitui Central using descriptive design. She classified the management practices as, communication, supervision and motivation; she established that all the three practices had influence on students' academic performance. However, using the same design, this study used the transformational leadership practices of a principal as identified by Leithwood (2010). Leithwood identified setting direction as one of the practices of transformational leadership with communication as an indicator. The current study will seek the perception from both teachers and student.

A study conducted Ross and Gray (2006) on transformational leadership and students' achievement involved 3042 elementary teachers in 205 schools in Ontario, Canada. They built teachers' professional commitment and beliefs in their collective capacity through raising their values and motivating them to go beyond self interest to embrace organizational goals. They found that principals who adopted transformational leadership style had a positive impact on teachers' beliefs in collective capacity and commitment to organizational values. But they did not relate specific practices of transformational leadership to academic performance. Further Ross and Gray (2006) concentrated on the perception of teachers only, and ignored the perception of the students.

On transformational leadership and teachers' perceptions, Aydın (2012) conducted a study in Istanbul. He found that principals' who exhibited inspirational motivation behavior, and set direction had highly motivated teachers. The principals were found to set high academic standards by visualizing success stories on the walls. But like Ross and Gray (2006), Adyn (2012) concentrated only on teachers' perceptions and ignored students. Principals are supposed to demonstrate a commitment to the mission and goals of their schools. Starcher (2006) observes that in modeling the way, effective principals know their own voices and are deeply committed to their beliefs, values and principles. By setting the examples, they demonstrate a commitment to the organization and its people. Apart from teachers' perception on principals, the current study will also seek to know how students perceive their principals.

In Tanzania, Nguni, Sleegers and Denessen (2006) surveyed 560 teachers in 70 primary schools, through path analysis, and found that transformational leadership behaviors had strong to moderate positive effect on teachers' job satisfaction, organizational commitment, and organizational citizenship behavior. Charismatic leadership had the greatest effect and accounted for the largest proportion of variance of the three variables. But individualized consideration had a very weak and insignificant effect. Intellectual stimulation had a weak influence on job satisfaction, but active management had a moderate positive influence on commitment to stay. However, they did not factor in students achievement in their study, the current study will be carried out in public secondary schools in Kisumu, with an aim of seeking teachers and students' perception on the principals' practices.

The Kenya government's Master Plan on Education and Training (1997-2010) noted that majority of schools fall short of providing the leadership needs of their students, resulting in poor academic performance (Ministry of Education(MoE), 2010). The Basic Education Act No. 14 of 2013 has delegated the management of basic education to principals. Under the regulation, the principal is the accounting officer, lead educator, and team leader for implementation of policies and primary initiator of policy proposal (GOK, 2013). Therefore the principal is the main character in defining the educational achievement of a school in Kenya. The government of Kenya through the Economic Recovery Strategy for Wealth and Employment Creation (ERS), (2003- 2007) made a policy decision to introduce performance contracts in the management of the public service. On this strength the Teachers' Service Commission (TSC) have made principals to sign performance contracts (PC) from January 2016 anchored in the provisions of the TSC Act 2012. The sole reason for this was to improve efficiency and effectiveness in the management of schools. The principal sign in person the PC to commit oneself to working towards achieving the performance target. The principals' employer recognizes that they are solely responsible for all that take place in schools.

\subsection{Statement of the Problem}

The Kenya Government's dream of integrating the youth into economic development master plan can only be achieved if secondary school students score grades that can enable them transit to tertiary education. The government introduced free day secondary education by paying tuition fee for every student. Other stakeholders and educational development partners have supported in the provision of infrastructure and other facilities in 
schools. Further, the principals have undergone in-service training to acquire the skills needed. Despite these efforts, academic performances of students have generally remained poor in Kisumu County. Between 2010 and 2014, only $35 \%$ of students from Kisumu County scored at least $\mathrm{C}+$; the minimum entry requirement to join universities. Educational Stakeholders blame poor students' academic performance on principals. As a result, $14.7 \%$ of the principals have been dropped while $39 \%$ transferred in the last 5 years. This study sought to establish the perceptions of students on principals, setting direction on academic performance in public secondary schools in Kisimu County, Kenya.

\subsection{Significance of the Study}

The findings of this study would provide useful information to school principals in the assessment of their leadership strengths and weakness in setting direction. With such information, the schools management boards and the in charge educational quality could obtain valuable information for guidance on the issues of focus to improving academic performance. Data and information from this study could be useful to: the Kenya Educational Management Institute (KEMI); the trainers of head teachers and school principals, policy makers in institutions of higher learning, and directorate of quality assurance. With the information on the leadership practices that promote quality of education now available, they could build these programs into specific units for quality improvement.

\subsection{Research Methodology}

The study employed a descriptive design. This was used because surveys essentially explore, describe and explain opinions attitudes and perceptions of groups of interest to a researcher (Oso, 2016). A survey was suitable since the study wanted to explore the perceptions of teachers and students on the role of the principal in setting direction on academic performance. The study used mixed methods in analyzing data involving qualitative and quantitative methods. The study targeted 204 principals of schools, 2196 teachers and 13213 form three students. The study used stratified, purposive and simple sampling techniques to select a sample of 152 schools 333 teachers and 378 students. Questionnaires and interviews were used to collect data.

\subsection{Results and discussion}

\subsection{Setting Direction and Students' Academic Performance}

Having established the status of setting direction by principals, the researcher investigated the relationship between setting direction and academic performance of students. The academic performance was obtained from the average mean score of a school from 2010 - 2014 coded as 1, 2, 3, 4, 5 and 6 as shown in Table 4.1. The average academic performance of the schools were compared against the status of setting directions by principals using linear regression to determine if there was significant variation in academic performance and setting direction by principals and test the null hypothesis that:

$\mathrm{H}_{\mathrm{o} 1}$ : Setting directions by principals does not have a significant influence on academic performance of students in secondary schools in Kisumu County.

The results summarized in Table 3.1 were obtained. 
Table 3.1

Regression of Academic Performance on Setting Directions by Principals

\begin{tabular}{lllllllll}
\hline Model & $\mathrm{B}$ & $\mathrm{R}$ & $\mathrm{R}^{2}$ & $\mathrm{~K}_{\text {adi }}^{2}$ & Std. $\varepsilon$ & $\mathrm{F}$ & $\mathrm{T}$ & Sig. \\
\hline Constant & 1.817 & & & & & & & \\
Setting Directions & .201 & .342 & .117 & .104 & .989 & 9.378 & 3.157 & .002 \\
\hline
\end{tabular}

Note. $\mathrm{F}(1,575)=9.378 ;$ Std. $\varepsilon=$ standard error 0.989

The F statistic in Table 3.1 indicates the overall significance of the regression model; $\mathrm{F}(1,575)=9.378, p=$ .002. These led to the rejection of the null hypothesis. Academic performance of students in schools with good setting directions by the principals was higher than academic performance of students in schools with poor or moderate setting directions by the principals. The study therefore established that setting directions by the principals has a significant influence on the academic performance of students in secondary schools in Kisumu County. Hence, developing a vision, articulating it and translating it into objectives positively affect students' academic performance; similarly, creating performance expectations and communication by principals affect academic performance of students.

In Table3.1, $\mathrm{R}$ indicates the multiple linear correlations between academic performance and setting directions by the principals. $\mathrm{R}=.342$ shows that there is a moderate positive association between setting directions by the principals and academic performance. Academic performance improves as setting directions improves. Further, $\mathrm{R}^{2}$ is the proportion of the variance in academic performance that is explained from the status of setting directions by the principals. $R_{\text {aci }}^{2}=.117$. This indicates that about $11.7 \%$ of the variance in academic performance of students in secondary schools in Kisumu County can be explained from the knowledge of the status of setting directions by the principals. The rest $88.3 \%$ of the variance in academic performance are due to other factors.

Further in Table 3.1, B is the un-standardized regression coefficient representing the weight of setting directions by the principals on academic performance, and its strength in the regression model. From the value of B and the constant term, a regression equation was developed as;

$$
\mathrm{F}^{\mathrm{I}}=1.187+0.201 \mathrm{SD} \ldots \mathrm{Fq} 1 .
$$

Where SD is the status of setting directions by the principals, and $\mathrm{P}^{1}$ is the predicted academic performance of the school. This shows that for a unit change in setting direction by principals, academic performance changes by about 0.2 units, other factors not withstanding.

The principals were also interviewed, to enable further clarification on the influence of setting directions on students' academic performance. Majority $(96.70 \%)$ of the principals interviewed supported the view that setting direction is a key determinant of students' academic performance. One principal remarked, 'My duty is to set directions for all personnel in the school. This is what I do every minute in the school'.

Another one noted, 'Without clear directions, both teachers and students lose focus and academic performance falls. They all need directions at various levels'.

Most principals $98.8 \%$ agreed that their schools had visions; however the time for the schools' vision to be actualized was not factored. Another $36 \%$ of the principals explained that they had broken their school visions into goals and objectives to be achieved within a specific period, $60 \%$ said they initiated the process that engage teachers and students in the development of a shared vision because everybody wants good academic achievement. All the principals did accept that they use all the available opportunity to communicate the shared mission to teachers, non teaching staff, students, and board of management, parents and the community at large.

On creating high performance expectations, all the principals interviewed acknowledged that their core business in school was to lead both the teachers and students into achieving optimal academic performance, they encourage students to work hard in their academics. One of them had this to say, 
"My teachers and I have created extra time to aid weaker students into achieving academic success."

While another added that, "I ensure the syllabus is completed in time and adequate revision done." All the principals agreed that they expected teachers to be professional, creative and hard working, however $72 \%$ said they motivate their teachers to achieve subject and school targets.

On fostering goal setting $40 \%$ of the principals interviewed said they guide the teachers and students on how to establish goals which they review from time to time. Another $30 \%$ say they expect teachers to set their own goals as long as it is in tandem with the school goals. Most of the principals agreed that they are a resource to helping teachers achieve both individual and school goals. The principals acknowledged they set quality direction for both teachers and students as they focus on the process of achieving academic success and the outcome in KCSE examination.

Through document analysis, the researcher reviewed school documents like strategic plans, past KCSE results, disciplinary book, departmental schemes of work, and records of work. The researcher found that $62 \%$ of the schools had strategic plans; however $38 \%$ had no strategic plans. A strategic plan is a road map to achieving organizational goals. From the strategic plans analyzed one of the key aspects was on the school improvement plans on KCSE examinations through a better school mean score. During the analysis the researcher realized though some schools had strategic plans, they were hardly used as what was stated in the strategic plans were not related to the actual status on the ground in the schools. This is an implication that principals were not setting directions at all in schools with no strategic plan for the future. The mean score of schools who had no strategic plan were below 5.00 from the documents analyzed. It was therefore obvious that principals were not doing much in providing the setting direction that leads to high academic standards. They wished their schools improve but were not planning anything towards the improvement.

It was observed that while principals take different approaches to provide directions for their school; they all set directions in one way or the other. In fact majority of the schools $(68.80 \%)$ were found to have set targets for form four KCSE performances, which was an indicator that principals had the notion of setting direction. However it was glaring clear that in most of the schools targets were only set for the Form four classes while other classes had no indications that targets were set for them. It was experiential that some schools had targets stipulated at class level, only $21 \%$ of the schools had target set for all classes in the school. It was also observed that all schools had a written formal vision and mission statements at the entrance to the school which was a clear evidence of setting direction, though this was not replicated in staffrooms or classes for most of the schools in Kisumu County only $37.8 \%$ of the schools had these statements visibly displayed almost everywhere in the school, like at the school the gate, the administration block and the principal's office, staffroom and classes. This implies principals in such schools don't continuously articulate the school vision, mission and goals. It was found that about $30 \%$ of the schools had set targets for students' academic performance which was visible to all.. The findings that setting direction has a significant effect on academic performance therefore resonated with what and how the principals thought and felt about settings directions and students academic performance. This findings echoes those of Mgani (2013) who found that out of the three schools where he conducted the research in Morogoro Tanzania, two had school mission and vision, and the mission and vision statements put on notice boards in the principal's office, staffrooms and classes.

The study therefore established that directions setting by the principals had a significant influence on the academic performance of students in secondary schools in Kisumu County $(\mathrm{F}(1,575)=9.378, p=.002)$, and that setting direction accounts for about $11.7 \%$ of the variance in academic performance of students in secondary schools in Kisumu County.

The relationship between setting direction and students' academic performance can be understood from the views of Marks and Print (2003), and Leithwood (2008) on setting directions. Marks and Print (2003) view setting direction as plotting the big picture while Leithwood (2008) view it as focusing on the activities that builds a clear vision, establishes goals, and create high performance expectations. It is about developing a shared understanding about a school. Generally, setting direction provides a sense of purpose and identity and gives the school a way to measure and monitor daily routines and to prioritize activities that directly contribute to furthering the school's goals and vision. Such a situation translates into positive performance improvement.

The findings of this study concurs with the findings of Valentine and Prater (2011) who investigated the relationship between different forms of leadership exhibited by school principals and academic achievement of their students. They found transformational leadership to be strongly and positively related to academic performance. This finding is also in agreement with the findings of a study by Rutledge (2010) who investigated 
categories of transformational leadership and academic optimism. he found that setting direction had significant effect on academic performance, and that it accounted for about $20 \%$ of the variance in academic performance, $\mathrm{r}=.45, \mathrm{p}<.01$. This corresponds very well with the findings of this study which is significant at $.05, \mathrm{r}=.211$.

Further, the finding concurs with the finding of a study by Namango and Bichanga (2014) who investigated the influence of strategic planning on academic performance in KImilili, Bungoma Sub County They found that there was a positive and significant $(\mathrm{p}<0.05)$ influence of school vision and academic performance in public secondary schools in Kimilili. This finding also supports the findings of Nguni et al. (2006) from a survey of teachers in primary schools in Tanzania. Nguni et al. (2006) found that transformational leadership behaviors had a positive effect on teachers' job satisfaction, organizational commitment, and organizational citizenship behavior. These translated into positive values in students which were reflected in improved academic achievement.

These studies form the foundation of the argument that transformational leadership has a significant effect on academic performance. This is because, as Limsila and Ogunlana (2008) point out, setting directions enable proper communication of expectations which in turn enhances teachers' perceptions of the gap between what the school is currently accomplishing and what it aspires to achieve. It also enables principals, as Aydin (2012) points out, to set high academic standards by visualizing success stories and demonstrating a commitment to the mission and goals of their schools. When high expectations are set, then focus is put on processes and outcomes. Therefore setting directions is the basis for principals to provide models, identify visions and foster school goals. It encourages high performance expectations and utilization of practices which demonstrate the leader's own expectations for excellence on the part of the followers. Similarly, the study is in support of Ndinza (2015) who established that effective communication by head teachers influences academic performance of students because it enables teachers and students to clearly understand what is expected of them.

\subsection{Conclusion}

This study sought to establish the perceptions of principals in setting direction on academic performance of students in secondary schools in Kisumu County. It was found that Setting directions by the principals had a significant influence on the academic performance of students in secondary schools in Kisumu County, [F ( 1 , $575)=9.378, p=.002]$, based on the regression equation,

$$
\mathrm{P}^{\mathrm{I}}=1.167+0.201 \mathrm{SD} \text {. }
$$

\subsection{Recommendations}

Based on the findings and the conclusion drawn above, the study makes the following recommendations:

The study recommends that all school be required, as a policy, to have strategic plans and that all leaders be inducted on the development of strategic plans. This way, they will be able to not only have the plans, but have basic knowledge on its development, implementation, management and evaluation. Further, they should be allowed to allocate funds for the venture.

\section{REFERENCES}

Amin, M. E. (2005). Social Science Research: Conception, Methodology and Analysis; Kampala, Makerere University Printery.

Best, W. J. \& Kahn, V. J. (2006). Research in Education. (10 ${ }^{\text {th }}$ ed.) Boston, Prentice Hall: Pearson.

Castanheira, P. \& Costa, J. A. (2011). In search of transformational Leadership: A (meta) analysis focused on the Portuguese reality. $3^{\text {rd }}$ World Conference on Educational Sciences. Vol.15

Coelli , M.and Green, D.[2012] ''Leadership effects; School Principals and students outcomes" Economics of Education of Review, vol 31,No 12012 PP 92-109

Dhuey, E. and Smith, J.(2014) 'How important are school. Principals in the production of Student Achievement", Canadian Journal of Economics, vol 47, No. 22014 pg 634-663

Groom, J. R. (2013). A Study of the Articulated Leadership Practices of Principals in Relation to the Literature on the Characteristics of High Performing Principals. Set Hall University Dissertations and Theses (ETDs) Paper 1930

Kothari, C. R. (2004). Research Methodology: Methods \& Techniques, $2^{\text {nd }}$ ed. New Age International (P), Publishers; New Delhi.

Leithwood K.A. and Riehi C. (2003). What we Know about Successful school leadership. Philadelphia, P A Laboratory for student success, Temple University.

Leithwood, K. and Sun, J. (2012). The Nature and Effect of Transformational School Leadership: A Meta Analytic Review of unpublished Research. Educational Administration Quarterly, 48(3), 3 87_423. ISS 1552_3519. 
Leithwood, K., \& Mascall, B. (2008). Collective leadership effects on student achievement. Educational Administration Quarterly, 44, 529-561

Leithwood, K. Harris, A. \& Hopkins, D. (2008). Seven strong claims about successful school leadership. School leadership \& Management, 28 (1), $27-44$.

Leithwood, K. (2010). Transformational school leadership. In E. Baker, B. McGaw, \& P. Peterson (Eds.), International encyclopaedia of education: Leadership and management-School Effectiveness. Oxford: Elsevier. Retrieved from http://www.credoreference.com.ipacez.nd.edu.au/entry.do?id=10428177

Limsila, K., \& Ogunlana, S. O. (2008).Performance and leadership outcome correlates of leadership styles and subordinate commitment. Engineering, Construction and Architectural Management, 15(2), 164-184.

Loeb, S., Kalogrides, D., and Beteille T.[2012] Effective Schools, Teachers Hiring, Assignment Develpoment and Retention, Education Finance and Policy,vol. 7 No. 3, 2012, pp 269-304

Ministry of Education (2012). A policy Framework for education and training; Sessional Paper 14 of 2012 Republic of Kenya

Mugenda, O. M. \& Mugenda, A. (2003). Research methods: Quantitative and Qualitative Approaches. Nairobi:ACTS Press, Nairobi.

Murphy, S. E., \& Ensher, E.A. (2008).A qualitative analysis of charismatic leadership in creative terms: The case of television directors. The Leadership Quarterly,

Namango, W. D \& Bichanga O. W. Influence of Strategic Planning on Academic Performance: A Hcase of Public Secondary School in Kimilili - Bungoma District. International journal of innovative research \& development

Nderitu, A. (2012). Transformational leadership characteristics on Students achievement; Published Thesis, Nairobi University, Nairobi; Kenya.

Ndinza, K. L. (2015) Influence Of Head teachers' Management Practices On Students' Academic Performance In Public Secondary Schools within Kitui central district, Kitui County, Kenya. Published research project

Nguni, S., Sleegers, P. J. C. \& Denessen, E. (2006).Transformational and transactional leadership effects on teachers' job satisfaction, organizational commitment, and organizational citizenship behavior in primary schools: The Tanzanian case School. Effectiveness and School Improvement, 17, 145-177.

Onyango, P. 2015). School Heads Blamed over poor performance; Nairobi, Kenya. The Standard Friday March $6^{\text {th }}$.

Orodho, J. A. (2008). Techniques of Writing Research Proposals\& Reports in Education and Social Sciences. Maseno; Kanezja HP Enterprises.

Oso, W. Y. (2016). Social Sciences Research; Principles and Practices. Nairobi: Jomo Kenyatta Foundation.

Oso, W. Y. (2016). Data Analysis. Introduction to Statistical Methods in Social Sciences. Kampala, Uganda: Makerere University Printy

Oso, W. Y. (2009). Writing Research Proposal and Report. Nairobi, Jomo Kenyatta Foundations

Oso, W. Y. \& Onen, D. (2009). Writing Research Proposal and Report. Nairobi, Jomo Kenyatta Foundations.

Republic of Kenya, (2005a). Kenya Education Sector Support Program 2005-2010. Delivering quality education to all Kenyans. Nairobi: Government Printer.

Republic of Kenya (2013). The Basic Education Act 2013.

Ross, J., \& Gray, P. (2006). Transformational leadership and teacher commitment to organization values: The mediating effects of collective teacher efficiency. School Effectiveness and School Improvement, 17(2), 179-199.

Simola, S., Barling, J. \& Turner, N. (2012). Transformational Leadership and Leaders Mode of Care Reasoning: Journal of Business ethics 6(2), 229-237.

Smith, S.C., \& Piele, P.K.(2006). School leadership: Handbook for student learning ( $4^{\text {th }}$ ed.) Thousand Oaks, Calif, Corwin. Starcher, G. (2006).Towards a new paradigm of management. European Bahai Business forum Stone.

Teachers Service Commission Act No. 20 of 2012 Revised Edition 2012. National Council for Law Reporting.www.kenyalaw.

United States of America ( 2015) Every Student Succeed ACT 2015

Valentine, J. \& Prater, M. (2011). Instructional, transformational and managerial leadership and student performance: Retrieved from http//dtpr.lib.athabascau.ca/action/download.

Wallace Foundation, (2016) school leadership; Building skills.Marzano Centre 